\title{
ДЕЦЕНТРАЛІЗАЦІЯ ПУБЛІЧНОЇ ВЛАДИ В КОНТЕКСТІ СУЧАСНОГО РОЗВИТКУ УКРАЇНИ
}

Коваленко Н.B., канд. наук 3 держ. упр., Національна академія державного управління при Президентові України, м. Київ, Україна.

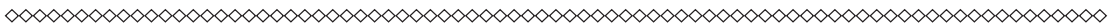

У статті розглянуто концептуальні засади децентралізації публічної влади. Встановлено, щзо різноманітність позицій щзодо визначення концептуальних засад децентралізації влади обумовлена різними причинами запровадження децентралізації влади в країнах світу.

Здійснено огляд реформи місиевого самоврядування на засадах децентралізації публічної влади. Визначено позитивні сторони та основні вади реформаторських дій.

Наголошено, щуо децентралізація сама по собі не є панацеєю для вирішення всіх проблем, які роками накопичувалися на місиевому рівні. Децентралізація буде ефективною лише за умови наявності централізачії влади, тобто їх ефективного поєднання. Саме належний їх баланс є важливим для ефективного та результативного функиіонування державного управління та формування спроможних інститутів місцевого самоврядування. Визначено, що успішність реформи децентралізації залежить не лише від інституційної спроможності та політичної волі місцевих посадовиів та депутатів, а й від рівня безпосередньої активності та участі мешканців у реалізації реформи на усіх ї̈ етапах.

Децентралізація влади посідає стратегічне місие у забезпеченні ефективності функціонування системи державного управління, основним критерієм результативності якої є реалізація інтересів та потреб громади. За умови законодавчого забезпечення та створення умов для співпраці влади, бізнесу та громадянського ISSN 2616-6216. Publ. upr. reg. rozvit. 2020, 8: 563-583 
«Public Administration and Regional Development»

https://pard.mk.ua/index.php/journal

суспільства, децентралізація буде поштовхом до мобілізачії суспільства, щзо призведе до підвищення його активності у процесах прийняття та реалізації управлінських рішень, а з іншої сторони сприятиме підвищенню ефективності роботи державного механізму й активізації розвитку регіонів через прийняття складних та оперативних рішень, запит на які дає суспільство.

У статті визначено чинники спротиву децеентралізації влади, серед них: - недостатнє залучення громадськості до практичного втілення реформи; бракінформаціїна початкуреформи, нерозуміння іï сутності; недостатнє усвідомлення щуодо подальших перспектив та наслідків втілення реформи; відсутність нормативно-правового поля та його прийняття по ходу реалізації реформаторських дій; відсутність стратегічного бачення розвитку краӥни після 2020 року; неготовність та неприйняття місцевих керівників запроваджуваних змін;небажання змін, як до суспільних настроїв так і управлінської еліти та ін.

Здійснено огляд нормативно-правового забезпечення реформи та запропоновано зміни щзодо удосконалення законодавстваз питань децентралізачії влади в Україні.

Визначено подальші кроки децентралізащії публічної влади в контексті сучасного розвитку Украӥни: завершити формування та ухвалення нормативно-правової бази реформи; визначити механізм вирівнювання диспропориій у рівнях розвитку регіонів України; вирішити питання забезпечення кваліфікованими кадрами; затвердити заходи щуодо попередження корупиії на місиевому рівні; сприяти формуванню сприятливого бізнес-середовища та інвестииійної привабливості тощуо.

Ключові слова: децентралізачія, реформа, публічна влада, розвиток суспільства.

Постановка проблеми у загальному вигляді. Подальший розвиток демократичних традицій публічного управління в Україні нерозривно пов'язаний із поглибленою децентралізацію владних 
Децентралізачія публічної влади в контексті сучасного розвитку Украӥни

відносин та розбудовою громадянського суспільства. Зміни, що відбуваються останнім часом в Україні, спрямовані на прискорення євроінтеграційних процесів та розбудову ефективної системи публічного управління. Сучасні тенденції організації державної влади країн СС базуються на іiі децентралізації, поєднанні із спроможними інститутами місцевого самоврядування. Розгортання моделей децентралізації управління державою є однією із новітніх тенденцій перетворень державно-управлінських систем.

Нинішній стан України потребує реформування та внесення суттєвих змін, спрямованих на створення відкритої та прозорої системи органів публічної влади. Децентралізація владних відносин на засадах субсидіарності визнана на офіційному рівні сьогодні пріоритетною серед інших реформ в Україні.

Останні дослідження демонструють позитивні зміни від створення ОТГ: ремонт, будівництво, освітлення територій. Однак видатки ОТГ часто йдуть на проїдання, зокрема, утримання органів управління, аніж інвестиції в розвиток. Громади отримали більше фінансових ресурсів, прямі відносини 3 Державним бюджетом, ширші повноваження й обов'язки та, разом 3 тим, залишаються невирішеними низка проблем організаційно-правового характеру.

Зневіра в успішній реалізації реформи як з боку влади, так і 3 боку населення, гальмують процеси децентралізації. Відсутність управлінського досвіду та небажання брати на себе відповідальність, враховуючи прогалини у законодавчому забезпеченні, не сприяють зміцненню місцевого самоврядування, наближенню влади до населення.

Аналіз останніх досліджень і публікацій. Загальним питанням децентралізації публічної влади присвячені праці багатьох науковців та політичних діячів, серед яких можна назвати Г. Возняк, Ю. Ганущак, В. Гройсман, Я. Жаліло, Т. Забейворота, В. Мамонова, Н. Нижник,С. Романюк та ін.

Серед зарубіжних дослідників децентралізаційних процесів варто зазначити: Г. Апель, Б. Бузан, Б. Гурне, Л. Діамонд, З. Леонский, Чейм Г. Шаббір та ін.

Дослідженням реформи в Україні сприяють програми співробітництва, міжнародні проекти та гранти. 
«Public Administration and Regional Development»

https://pard.mk.ua/index.php/journal

Формулювання цілей статті (постановка завдання) представлення результатів дослідження децентралізації публічної влади в контексті демократичних перетворень та сучасного розвитку України.

Виклад основного матеріалу дослідження. На сучасному етапі Україна неухильно спрямовує свої зусилля на реалізацію євроінтеграційного курсу, виконання міжнародних зобов>язань, спрямованих на подальший розвиток суспільства, що потребує освоєння реформаторського шляху продуманих і реалізованих за ефективними технологіями змін, які дозволять без втрат і руйнувань досягти якісного оновлення суспільних відносин.

Задля більш повного відображення змісту наукового дискурсу щодо процесів децентралізації управлінських відносин, який точиться як у країнах із найбільш розвиненими демократичними традиціями, так в межах вітчизняної наукової спільноти, наведемо декілька точок зору провідних вчених, у яких децентралізація розглядається 3 різних точок зору, але у цілому вона сприймається як природна еволюція системи публічного управління.

Спочатку варто згадати, що сам перехід до децентралізованого управління $\epsilon$ характерною ознакою для великої кількості як розвинених країн, так i країн, що розвиваються. За даними Світового банку, 63 із 75 трансформаційних країн і великих країн, що розвиваються, в середині 90-х рр. XX ст. здійснили кроки в напрямі децентралізації [1].

L. Diamond в своїх дослідженнях стверджує, що децентралізація сприймається як засіб надання різним етнічним і регіональним групам деякої автономії і контроль над своїми власними справами. Ідея полягає в тому, що якщо різні етнічні та регіональні меншини мають деяку автономію, деяку здатність визначати свої власні місцеві справи стосовно освіти, культури та економічного розвитку, то вони будуть почувати себе в більшій безпеці, і будуть більш готові прийняти повноваження і легітимність. По-друге, децентралізація влади сприймається як засіб поділу влади між великою кількістю різних політичних партій. Партії і групи, які не можуть отримати контроль центрального уряду, можуть 
Децентралізачія публічної влади в контексті сучасного розвитку України

виграти можливість здійснювати владу в управлінні нижчого рівня. Це підвищує їх впевненість і прихильність до політичної системи, відчуття громадян, що система $\epsilon$ справедливою. Потретє, демократія прокотилася по всьому світу, як основна цінність та основа управління. I децентралізація розглядається як основоположний демократичний принцип. Цього не достатньо для людей, щоб просто бути в змозі вибирати своїх національних лідерів в періодичних, вільних і справедливих виборах. Демократія вимагає, щоб люди змогли обрати своїх місцевих керівників та представників, які через місцеві органи влади будуть мати реальну владу для реалізаціїпотребмешканців [2].

Дещо іншу точку зору має Л. Гамбург,який зазначає, що децентралізація ставить за мету «підвищення ефективності роботи державного механізму й активізації розвитку регіонів і муніципій на засадах демократії, а показниками такої ефективності й активізації $\epsilon$ повноцінне забезпечення прав, законних інтересів та обов'язків місцевого населення, структурованого в комунально-муніципальні та регіональні колективи, а також органи територіальної самоорганізації» [3, с.140].

Децентралізацію публічної влади розуміють i як процес перерозподілу владних повноважень та обсягів компетенції між центральним i місцевими рівнями організації публічної влади зі зміщенням акценту виконання на місцях у частині здійснення заздалегідь окреслених і гарантованих державою функцій. Так, С. Кіщевський стверджує, що саме децентралізація є політичною ідеєю, котра визначає, що субнаціональні органи влади отримують деяку політичну автономію разом із новими функціями та ресурсами [4, с. 170$]$.

Автономізація публічного управління через децентралізацію $є$ найбільш поширеною соціальною практикою, проте варто звернути увагу й на провідних суб'єктів - органи місцевого самоврядування. Отже, якщо децентралізація тісно пов'язана 3 організацією системи державного управління, то вона має на меті сприяти побудові ефективних взаємовідносин між центральним урядом й органами управління на локальному рівні Тобто децентралізація ISSN 2616-6216. Publ. upr. reg. rozvit. 2020, 8: 563-583 
«Public Administration and Regional Development»

https://pard.mk.ua/index.php/journal

- це розширення і зміцнення прав та повноважень місцевого та регіонального самоврядування стосовно незалежного прийняття рішень та виконання, делегованих державною владою, повноважень [5].

Дуже цікавою $€$ точка зору Р. Мінченко, який у своїх дослідженнях зазначає, що «децентралізація влади в системі державного управління» відображає цілеспрямований процес, орієнтований на покращення державного управління, включає в себе переміщення від вищих до нижчих рівнів органів державної влади й місцевого самоврядування [6, с. 452].

Поняття «децентралізації влади» здобуло класичне тлумачення у дослідженні французького дослідника Б. Гурне «Державне управління». Автором було акцентовано, на тому що «децентралізація - це спосіб територіальної організації влади, за яким держава передає право на прийняття рішень 3 певних питань або у певній сфері структурам локального чи регіонального рівня, що не входять до системи виконавчої влади і є відносно незалежними від неї» [7, с. 88].

При визначенні терміну «децентралізація» окремі дослідники, зазначили, що «децентралізація»: - це передавання від центральної влади відповідальності. Так, у монографії американського вченого Чейма Г. Шаббіра «Управління децентралізацією: нові концепції та практики» підкреслено, що «децентралізація влади - це передавання повноважень, відповідальності та ресурсів через механізм деконцентрації влади, тобто делегування повноважень від центру - до нижчих рівнів органів виконавчої владної вертикалі» [8, с. 1].

Деякі дослідники вважають, що децентралізація має певні демократичні переваги, оскільки передбачає передачу управління максимальним числом справ в руки безпосередньо зацікавлених осіб або їх представників [9].

У монографії С. Романюка «Децентралізація: теорія та практика застосування» зазначено, що децентралізація, як передавання повноважень та ресурсів від ЦОВВ, не може розглядатися як самоціль: нерідко іï пов'язують із демократичними та політичними процесами, невиправдано залишаючи осторонь раціональну 
Децентралізачія публічної влади в контексті сучасного розвитку України

складову. Ось чому здійснення децентралізації завжди повинно супроводжуватися вимогою ㄲi докладного проектування та оцінювання 3 точки зору іiі здатності (порівняно із централізацією) досягнути більш широких цілей - справедливості, ефективності, якості та фінансової обгрунтованості, а успіх децентралізації безпосередньо залежить від підготовки як центральних, так і місцевих органів влади до децентралізованого адміністрування [10].

Вважаємо, що різноманітність позицій щодо визначення концептуальних засад децентралізації влади обумовлена різними причинами запровадження децентралізації влади в країнах світу. Так, головною причиною запровадження реформи децентралізації влади у Канаді, Великобританії, Іспанії було збереження єдності багатоетнічної держави. У Канаді реформа децентралізації також була обумовлена необхідністю захисту мови франкомовних громадян по всій Канаді, зробивши Канаду двомовною [11]. Бажання зберегти єдність держави змусило уряд Великобританії й Іспанії запровадити децентралізацію влади [12, с. 388]. У Нідерландах і Данії запровадження реформи децентралізації обумовлена необхідністю підвищити ефективність роботи місцевих органів влади [13, с. 487].У посткомуністичних державах головною причиною запровадження реформи децентралізації стала необхідність розвитку місцевого самоврядування, а також запровадження місцевої демократії [14].

Незважаючи на наявність значної кількості тлумачень i дефініцій концептуальних засад поняття «децентралізація публічної влади», всі дослідники одностайні в тому, що головним принципом децентралізації $€$ субсидіарність. У науковому середовищі усталеною думкою можна вважати таку, у якій функції публічної влади, згідно з принципом субсидіарності мають бути передані від центральної влади (згори) на найнижчий рівень (початковий: місцевий, муніципальний) управління. Оскільки місцева влада максимально наближена до населення, саме на цьому рівні влади можна найефективніше вирішити більшість соціально-економічних проблем громадян.

Зауважимо, що не слід децентралізацію розглядати як панацею, яка здатна вирішити усі без винятку місцеві проблеми. 
«Public Administration and Regional Development»

https://pard.mk.ua/index.php/journal

Децентралізація буде ефективною лише за умови наявності централізації влади, тобто їх ефективного поєднання. Належний ï баланс $\epsilon$ важливим для ефективного та результативного функціонування усієї системи публічного управління. Адже не всі функції можуть (чи повинні) фінансуватися та виконуватися у децентралізований спосіб.

Вирішити проблему оптимального і раціонального поєднання централізації та децентралізації покликана адміністративна реформа в Україні. За Концепцією реформи, затвердженою урядом 1 квітня 2014 р., в Україні має бути побудована проста та логічна система місцевого самоврядування. Загалом, передбачено три етапи проведення реформи, результатом якої визначено: створення та підтримка належного життєвого середовища для громадян, надання високоякісних і доступних послуг, поява установ прямого народовладдя, задоволення інтересів громадян в усіх сферах життєзабезпечення на відповідній території, узгодженість інтересів держави та територіальних громад.

Заплановані зміни за умови їх реалізації у належний спосіб дозволять отримати переваги, які притаманні децентралізації публічної влади, що підтверджують наукові дослідження. Так, польський дослідник Z. Leoński визначає наступні переваги децентралізації: спрощення системи i процедури прийняття рішення; прозорість і відкритість процедур прийняття рішення та процесу його реалізації; підвищення свідомості та загострення почуття відповідальності за здійснені заходи і прийняті рішення; мінімізація бюрократизму; об'єктивна оцінка результатів прийнятих і реалізованих рішень тощо [15, с. 28-35].

Експерти Ради ООН поширення децентралізаційних тенденцій у різних національних системах державного управління розглядають як об'єктивний фактор, який, з одного боку, залежить від рівня громадської свідомості та самосвідомості, а з іншого - забезпечує налагодження партнерських відносин між органами державної влади та самоорганізаційними громадами. На їх думку, «реалізація різних форм децентралізаційних програм, в країнах сталого розвитку є тенденцією, яка пов'язана із зростаючим інтересом до 
Децентралізачія публічної влади в контексті сучасного розвитку України

ролі громадянського суспільства та приватного сектору як партнера для урядів, які перебувають у пошуку нових шляхів обслуговування громадян» [16].

Децентралізація влади посідає стратегічне місце у забезпеченні ефективності функціонування системи державного управління, основним критерієм результативності якої є реалізація інтересів та потреб громади. Відповідно, децентралізація - це «модель організації управлінської діяльності, яка дозволяє приймати складні та оперативні рішення, запит на які дає суспільство». Г. Апель зазначає, що децентралізація влади $€$ важливим інструментом розширення свободи громади, що призводить до підвищення іiі активності у процесах прийняття та реалізації управлінських рішень [17].

Існує думка, що лише децентралізація влади здатна забезпечити певну мобілізацію суспільства щодо пошуку позитивної динаміки у розвитку держави, що $\epsilon$ важливою складовою реалізації модернізаційних реформ. Мобілізація громадянського суспільства відбувається завдяки формуванню спільної відповідальності як певної форми громадянської самосвідомості [18].

В Україні реформу місцевого самоврядування на засадах децентралізації влади розпочато у 2014 році. Метою їі проведення $\epsilon$ відхід від централізованої моделі управління в державі, забезпечення самодостатнього місцевого самоуправління і побудова ефективної системи територіальної організації влади в Україні.

Суспільне забезпечення процесу децентралізації являє собою підтримку суспільством запланованих державних адміністративнотериторіальних перетворень. Згідно з дослідженнями, проведеними Асоціацією міст України у рамках проекту «Діалог», на кінець 2014 р., 68\% жителів міст знали про децентралізацію, а 58\% iï підтримували, 52\% вважали, що більшість повноважень має належати місцевому самоврядуванню, лише $20 \%$ очікували зростання якості надання послуг, 38\% підтримували об'єднання громад, а 25\% висловлювалися проти об'єднання [19, с. 48].

Загалом, аналіз досвіду децентралізації влади в Україні 20152018 рр. засвідчив наявність тенденцій певного спротиву реформі. 
«Public Administration and Regional Development»

https://pard.mk.ua/index.php/journal

На нашу думку, вагомими чинниками спротиву децентралізації влади є:

- недостатнє залучення громадськості до практичного втілення реформи, зокрема, слабка координація місцевої влади щодо забезпечення конструктивного діалогу між мешканцями під час обговорення добровільного об'єднання громад;

- брак інформації на початку реформи, нерозуміння іiі сутності;

- недостатнє усвідомлення щодо подальших перспектив та наслідків втілення реформи;

- відсутність нормативно-правового поля та його прийняття по ходу реалізації реформаторських дій;

- відсутність стратегічного бачення розвитку країни після 2020 року;

- неготовність та неприйняття місцевих керівників запроваджуваних змін;

- небажання змін, як до суспільних настроїв так і управлінської еліти та ін.

Відповідно до опитування думок людей, проведеного у рамках швейцарсько-українського проекту DESPRO [20] у 2015 р., існує гостра потреба в інформації щодо конкретних кроків реалізації реформи та очікуваних результатів. Брак чіткої інформації, відповідей на конкретні питання призводить до зневір'я, спротиву реформі, побоювань їі наслідків.

Соціологічне дослідження (опитування громадської думки для оцінки змін в обізнаності громадян щодо громадських організацій та їхньої діяльності, станом на кінець 2018 р.) встановило, що лише близько третини населення України регулярно або рідко брали участь у зборах громади та інших громадських заходах протягом 2018 р., тоді як дві третини не долучалися до таких заходів через брак часу або відсутність зацікавленості. Кожен п>ятий громадян готовий збирати підписи під зверненням до органів місцевого самоврядування, щоб вирішити місцеву проблему (19\%), проте половина (52\%) не готова піти навіть на такий крок [21].

В Україні реалізується другий етап реформи, який передбачає подальше формування спроможних громад, зміну територіального 
Дечентралізачія публічної влади в контексті сучасного розвитку Украӥни

устрою на рівні районів та громад, розмежування повноважень та функцій контролю різних рівнів управління, розвиток форм місцевої демократії, підвищення рівня сервісів у наступних галузях: охорона здоров'я, освіта, культура, соціальні послуги тощо.На даний час процес трансформації органів місцевого самоврядування поступово переходить у примусову форму (2020 р. завершується добровільне об'єднання громад), що безперечно знижує його реальну ефективність.

Проміжним результатом першого етапу реалізації реформи системи місцевого самоврядування стало співіснування двох типів самоврядування базового рівня в рамках унітарної держави. Оскільки не завершено перший етап формування адміністративнотериторіальних одиниць базового рівня, не можна говорити про остаточний перерозподіл повноважень між органами місцевого самоврядування різних рівнів та між органами місцевого самоврядування та виконавчої влади.

Аналіз нормативно-правового забезпечення реформи дозволив встановити, що з 2014 року сформовано значний масив нормативноправових актів у сфері реалізації реформи місцевого самоврядування на засадах децентралізації, зокрема щодо добровільного об'єднання територіальних громад, їх співробітництва, передачі повноважень від органів виконавчої влади до органів місцевого самоврядування, фінансової децентралізації тощо.

Для успішного завершення децентралізації необхідним $\epsilon$ прийняттященизкинормативно-правовихактів,якібиврегульовували невирішені питання децентралізації місцевого самоврядування. Саме відсутність нормативного поляне сприяє успішній реалізації реформи. Так, відсутність законодавчого врегулювання засад адміністративно-територіального устроюдозволяє стверджувати про відсутність логічної моделі децентралізації та неготовність управлінської системи до впроваджуваних заходів на її початку.

Незважаючи на наявність суттєвих політико-правових зрушень щодо створення законодавчої платформи для здійснення реформи децентралізації в Україні, багато iї питань та аспектів потребують подальшого удосконалення правового регулювання або взагалі заISSN 2616-6216. Publ. upr. reg. rozvit. 2020, 8: 563-583 
«Public Administration and Regional Development»

https://pard.mk.ua/index.php/journal

лишаються неврегульованими. Пропонуємо такі заходи щодо удосконалення законодавчого забезпечення реформи децентралізації в Україні:

- внесення зміни до Конституції щодо децентралізації, в першу чергу, в частині адміністративно-територіального устрою i місцевого врядування;

- прийняття законів: Прозасадиадміністративно-територіального устрою України», «Про службу в органах місцевого самоврядування» (нова редакція), «Про державний нагляд за законністю рішень органів місцевого самоврядування», «Про місцевий референдум», «Про муніципальну поліцію». Потребують оновлення закони про місцеві вибори, про місцеві державні адміністрації та ін.;

- вдосконалення підзаконних нормативно-правових актів щодо децентралізації публічної влади, зокрема, в частині чіткого встановлення термінів їх реалізації;

- нормативне визначення особистої відповідальності посадових осіб місцевих органів влади щодо виконання власних та делегованих повноважень, зокрема, ефективне використання комунальної власності тощо;

- чітке розмежування повноважень, зокрема поширення повноважень органів місцевого самоврядування на землі за межами населених пунктів (забезпечення принципу повсюдності);

- збільшення ресурсної бази громад, наприклад, через запровадженнямеханізму зарахування до місцевих бюджетів частини податку на прибуток підприємств, які здійснюють свою економічну діяльність в межах громади тощо.

Наукові публікації стверджують, що «наявність достатніх ресурсів у місцевих бюджетах $є$ запорукою того, що територіальна громада має можливість надавати більш якісні та більш різноманітні послуги своїм жителям, реалізовувати соціальні та інфраструктурні проекти та фінансувати інші заходи для всебічного покращення умов проживання жителів громади»[22]. Не погоджуємося з такими думками, оскільки:

- в утворених об〉єднаних територіальних громадах немає належно підготованих кадрів, спостерігається низька кваліфікація службовців 
Децентралізачія публічної влади в контексті сучасного розвитку Украӥни

місцевого самоврядування для виконання нових функцій;

- відбувається зростання навантаження на працівників у таких сферах, як охорона здоров'я, соціальна допомога, освіта, надання адміністративних послуг у результаті збільшення повноважень без відповідного матеріального заохочення, що суттєво знижує мотивацію й активність, а іноді і формує негативне ставлення до процесу децентралізації.

Система управління на рівні громад виявилася на сьогодні недостатньо спроможною для виконання у повному обсязі нових функцій та завдань. Розширення повноважень на місцевому рівні потребує кваліфікованих кадрів. Звідси два шляхи: навчати й підвищувати кваліфікацію, що є витратним та не визначеним у часі та другий - звільнити на найняти кваліфікований персонал, який буде здатний виконати нові функції.

Фінансова спроможність є передумовою успішної реалізації функцій та завдань на місцях, сприяє економічному розвитку ОТГ. На сучасному етапі варто створити сприятливі умови для подальшого розвитку об'єднаних територіальних громад, розширення власних джерел надходжень їх бюджетів, оскільки державна підтримка об'єднаних територіальних громад буде поступово скорочуватися. Одним із дієвих інструментів можна назвати створення сприятливого бізнес-середовища та інвестиційної привабливості. Так, автори аналітичної доповіді «Децентралізація влади: як зберегти успішність в умовах нових викликів?» (2018 р., Національний інститут стратегічних досліджень) пропонують побудову на місцевому рівні економіко-правового середовища, «дружнього до розвитку». В якості ознак «дружності до розвитку» локальної економічної системи автори доповіді розглядають [23]: диверсифікованість економіки території; пріоритетність розвитку секторів, які орієнтовані на розширення міжсекторальної співпраці; сталість розвитку; інтегральність; уникнення ризиків анклавізації місцевої економіки та їі відкритість до коопераційної взаємодії.

Зазначимо, що на міжнародному рівні, 3 урахуванням сучасних змін в технологіях та організації ведення бізнесу, наразі застосовується поняття «ділової екосистеми» (business ecosystem) 
«Public Administration and Regional Development»

https://pard.mk.ua/index.php/journal

як цілісного середовища реалізації підприємницької діяльності, яке починається з межі підприємства та закінчується на кордоні країни, складається 3 прибуткових (сервісних), неприбуткових організацій, локальної інфраструктури, системи освіти та кваліфікаційної підготовки тощо [24]. Сфера відповідальності громад в рамках «ділової екосистеми» розглядається насамперед у вирішенні проблеми «останньої милі»: локального середовища для малих і середніх підприємств, облаштування якого значною мірою є результатом публічних інвестицій у транспортну, шляхову, інформаційно-комунікаційну інфраструктуру, де на частку публічних коштів припадає 70\% фінансування. Крім цього, роль громад $є$ важливою у створенні загального ділового середовища, зокрема - забезпеченні та підтримці надання освітніх та професійно-освітніх послуг, створенні умов для діяльності, або й співзаснуванні організацій з підтримки торгівлі та інвестицій, створенні мотивації для збільшення обсягу приватних інвестицій у розвиток інфраструктури «останньої милі».

Налагодження прозорої взаємодії між керівництвом ОТГ та місцевим бізнесом $є$ пріоритетом для створення умов для розвитку території, сприяє формуванню ними спільного бачення майбутнього їхньої громади та потребує створення на місцевому рівні спеціалізованих дорадчих органів для розвитку бізнес-середовища, входження представників бізнесу до громадських рад громад тощо.

Найбільш загрозливим явищем у контексті децентралізації $€$ високий рівень корупції в Україні. Світовий досвід свідчить про недоцільність децентралізації бюджету за умови високого рівня корупції, відповідно особливу увагу необхідно приділяти питанню корупційної складової у діяльності органів місцевого самоврядування та децентралізації влади.Зменшенню корупції, на нашу думку, буде сприяти:

- визначення та закріплення в нормативно-правових документах особистої відповідальності посадових осіб місцевого самоврядуваннящодо виконання власних та делегованих повноважень;

- запровадження в Україні спеціальних фінансових служб контролю і аудиту місцевого самоврядування, позитивний вплив яких підтверджує досвід Литви; 
Дечентралізація публічної влади в контексті сучасного розвитку України

- визначення на законодавчому рівні переліку документів i проектів, які ОТГ повинні розміщувати у відкритому доступі;

- утворення при органах місцевого самоврядування консультативно-дорадчих органів для проведення консультацій з громадськістю, сприяння проведенню громадської експертизи проектів рішень та прийнятих рішень;

- державний нагляд та контроль за діяльністю органів місцевого самоврядування тощо.

Децентралізація відіграє важливу роль у демократизації i трансформації суспільства, відкриває перспективи для забезпечення спроможності місцевого самоврядування самостійно вирішувати питання місцевого значення; створює інструменти щодо задоволення культурної, мовної та етнічної різноманітності; розвиває економічну конкуренцію; підвищує роль громадян, їх вплив на процес прийняття й реалізацію рішень щодо забезпечення розвитку громади та суспільства в цілому.

- Щодо подальших кроків децентралізації публічної влади в контексті сучасного розвитку України необхідно:

- завершити формування та ухвалення нормативно-правової бази реформи;

- визначити механізм вирівнювання диспропорцій у рівнях розвитку регіонів України, враховуючи досвід європейських країн;

- вирішити питання забезпечення кваліфікованими кадрами, оскільки кадровий ризик $є$ одним 3 ключових викликів успішної децентралізації публічної влади;

- затвердити заходи щодо попередження корупції на місцевому рівні;

- стимулювати заходи щодо створення сприятливого бізнессередовища та інвестиційної привабливості із застосуванням європейського досвіду в рамках «ділової екосистеми»; сприяти прозорої взаємодії між керівництвом ОТГ та місцевим бізнесом; заохочувати створення спеціалізованих дорадчих органів для розвитку бізнес-середовища, входження представників бізнесу до громадських рад громад тощо. 
«Public Administration and Regional Development» https://pard.mk.ua/index.php/journal

Висновки. За результатами проведеного аналізу децентралізації публічної влади в контексті сучасного розвитку України: встановлено, що система управління на рівні громад виявилася на сьогодні недостатньо спроможною для виконання у повному обсязі нових функцій та завдань. Визначено, що подальший, динамічний розвиток місцевого самоврядування та в цілому успішне реформування публічної влади на засадах децентралізації в Україні можна забезпечити лише за умови удосконалення законодавчого забезпечення реформи. 3. З'ясовано, що успішність реформи децентралізації залежить не лише від інституційної спроможності та політичної волі місцевих посадовців та депутатів, а й від рівня безпосередньої активності та участі мешканців у реалізації реформи на усіх іiі етапах. 4. Перспективи подальших досліджень необхідно спрямувати на вивчення та пошук інструментарію владно-громадської взаємодії в контексті реформування місцевого самоврядування на засадах децентралізації.

\section{Стаття надійшла до редакції: 13.03.20}


Дечентралізація публічної влади в контексті сучасного розвитку Украӥни

\section{DECENTRALIZATION OF PUBLIC AUTHORITY IN THE CONTEXT MODERN DEVELOPMENT OF UKRAINE}

Kovalenko Nataliia, Ph.D in Public Administration, Associate Professor of department of public policy and political analytics NAPA, Kyiv, Ukraine

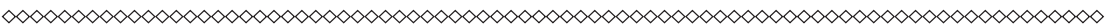

The article considers the conceptual principles of decentralization of public power. It is established that the diversity of positions on the definition of the conceptual basis of decentralization of power is due to various reasons for the introduction of decentralization of power in the world.

The review of local self-government reform on the basis of decentralization of public power is carried out. The positive aspects and main shortcomings of the reform actions are identified.

It is emphasized that decentralization in itself is not a panacea for solving all the problems that have accumulated over the years at the local level. Decentralization will be effective only if there is a centralization of power, ie their effective combination. It is their proper balance that is important for the effective and efficient functioning of public administration and the formation of capable institutions of local self-government. It is determined that the success of decentralization reform depends not only on the institutional capacity and political will of local officials and deputies, but also on the level of direct activity and participation of residents in the implementation of the reform at all stages.

Decentralization of power occupies a strategic place in ensuring the effectiveness of the public administration system, the main criterion for the effectiveness of which is the realization of the interests and needs of the community. Subject to legislative support and creating conditions for cooperation between government, business and civil society, decentralization will stimulate the mobilization of society, which will increase its activity in the process of making and implementing ISSN 2616-6216. Publ. upr. reg. rozvit. 2020, 8: 563-583 
«Public Administration and Regional Development»

https://pard.mk.ua/index.php/journal

management decisions, and on the other hand will increase the efficiency of the state mechanism and development regions through the adoption of complex and operational decisions, which are requested by society.

The article identifies the factors of resistance to decentralization of power, among them: - insufficient public involvement in the practical implementation of the reform; lack of information at the beginning of the reform, misunderstanding of its essence; insufficient awareness offurther prospects and consequences of the reform; the absence of a regulatory framework and its adoption in the course of the implementation of reform actions; lack of a strategic vision for the country's development after 2020; unpreparedness and rejection of local leaders of the introduced changes, unwillingness to change, both to public sentiments and the management elite, etc.

$A$ review of the regulatory and legal support of the reform was carried out and changes were proposed to improve the legislation on decentralization of power in Ukraine.

Further steps of decentralization of public power in the context of modern development of Ukraine are determined: to complete the formation and adoption of the regulatory framework for reform; to determine the mechanism of equalization of disparities in the levels of development of the regions of Ukraine; to resolve the issue of providing qualified personnel; approve measures to prevent corruption at the local level; to promote the formation of a favorable business environment and investment attractiveness, etc.

Keywords: decentralization, reform, public authority, development of society.

\section{Received: 13.03.20}

\section{References}

1. Bondarenko, A. I. (2010). Vplyv derzhavy na formuvannia mistsevykh biudzhetiv u krainakh Yevropy [The influence of the state on the formation of local budgets in European countries]. Retrieved from http://www.nbuv.gov.ua/ portal/Soc_Gum/Tpdu/2010_4/doc/2/13.pdf. [in Ukrainian].

2. Diamond, L. (2004). Why Decentralize Power in A Democracy? 
Децентралізація публічної влади в контексті сучасного розвитку Украйни

Conference on Fiscal and Administrative Decentralization. Baghdad, Iraq. Retrieved from https://web.stanford.edu/ ldiamond/iraq/Decentralize Power021204.htm [in English].

3. Hamburh, L.S. (2014). Teoretychni pytannia detsentralizatsii derzhavnoi vlady v systemi publichnoi vlady unitarnoi derzhavy [Theoretical issues of decentralization of state power in the system of public power of a unitary state]. Visnyk Zaporizkoho natsionalnoho universytetu - Bulletin of Zaporizhia National University, № 4 (I), 134-145. Retrieved from http://law. journalsofznu.zp.ua/archive/visnik-4-2014-1/20.pdf [in Ukrainian].

4. Kishchevskyi, S. (2015). Onovlennia Konstytutsii yak zavershennia revoliutsii [Renewal of the Constitution as the end of the revolution]. Tsentr perspektyvnykh doslidzhen - Center for Advanced Studies, № 1, 169-170 [in Ukrainian].

5. Drozdovska, O. S. (2012). Teoretychni zasady finansovoi detsentralizatsii [Theoretical principles of financial decentralization]. Finansy Ukrainy - Finance of Ukraine, № 8, 19-25 [in Ukrainian].

6. Minchenko, R.M. Problemy detsentralizatsii derzhavnoi vlady i yikh vzaiemodiia $\mathrm{z}$ mistsevym samovriaduvanniam $\mathrm{v}$ Ukraini [Problems of decentralization of state power and their interaction with local self-government in Ukraine]. Derzhava i pravo - State and Law, № 39, 452 [in Ukrainian].

7. Hurne, B. (1991). Derzhavne upravlinnia; per. z fr. V. Shovkun [Governance; lane. with fr. V. Shovkun]. Instytut derzh. upravlinnia ta samovriaduvannia pry Kabineti Ministriv Ukrainy. Kyiv. : Osnovy [in Ukrainian].

8. Cheema, G. (2007). Shabbir Decentralizing Governance Emerging Concepts and Practices. Washington, D.C: ash institute for democratic governance and innovation John F. Kennedy School of Government Harvard University [in English].

9. Roman, V. F. (2014). Osoblyvosti detsentralizatsii ta dekontsentratsii vlady: teoretychnyi aspekt [Peculiarities of decentralization and deconcentration of power: theoretical aspect]. Efektyvnist derzhavnoho upravlinnia - Efficiency of public administration, 38, 92-98. Retrieved from http://nbuv.gov.ua/j-pdf/ efdu_2014_38_11.pdf. [in Ukrainian].

10. Romaniuk, S.A. (2018). Detsentralizatsiia: teoriia ta praktyka zastosuvannia : monohrafiia [Decentralization: theory and practice of application: monograph]. Kyiv [in Ukrainian]. 
«Public Administration and Regional Development»

https://pard.mk.ua/index.php/journal

11. The Decentralization In Canada Politics Essay. All Answers Ltd. ukessays.com. (2013). Retrieved from https://www.ukessays.com/essays/ politics/the-decentralization-in-canada-politicsessay.php?vref=1 [in English].

12. Convery, A. \& Lundberg, T. (2017). Decentralization and the centre right in the UK and Spain: central power and regional responsibility. Territory, Politics, Governance, №5 (4), 388-405 [in English].

13. Ruano, J.M. \& Profi roiu, M. (2017). Conclusions: Intergovernmental Networks and Decentralisation in Europe. The Palgrave Handbook of decentralization in Europe. Palgrave Macmillan [in English].

14. Harald, B. \& Michal, I. \& Hellmut W. (Eds.). (2003). Local Democracy in Post-Communist Europe. Opladen: Leske Budrich [in English].

15. Leoński, Z. (2004). Nauka administracji. Warszawa : C.H. BECK, 28-35, 58-92 [in Polish].

16. Buzan, B. (2014). From International to World Society? N.-Y. : Cambridge University Press [in English].

17. Apel, K.-O. (2001). Bamberhskye lektsyy [Bamberg lectures]. Fylosofyia bez hranyts - Philosophy without borders, sb. stat. : v 2 ch. V.V. Myronova (Ed.), Moskva. : Yzdatel Vorobev, A.V. [in Russian].

18. Hroisman V. B. Ctrukturno-funktsionalna rol detsentralizatsii vlady u protsesakh stanovlennia hromadianskoho suspilstva [Structural and functional role of decentralization of power in the processes of formation of civil society]. Retrieved from http://www.lvivacademy.com/vidavnitstvo_1/edu_44/fail/ ch_1/29.pdf [in Ukrainian].

19. Zvit zaprovadzhennia proektu Dialoh [Dialogue project implementation report]. Retrieved from http://auC.org.ua/sites/default/files/zvitdialogue project_ukr.pdf [in Ukrainian].

20. Detsentralizatsiia: dumky liudei [Decentralization: people's opinions]. Retrieved from http://decentralization.gov. ua/info graphics/item/id/22 [in Ukrainian].

21. Opytuvannia hromadskoi dumky dlia otsinky zmin v obiznanosti hromadian shchodo hromadskykh orhanizatsii ta yikhnoi diialnosti (pidhotovleno dlia proektu ENGAGE na zamovlennia PactInc) [Public opinion poll to assess changes in citizens' awareness of NGOs and their activities (prepared for the ENGAGE project commissioned by PactInc)]. (2018). Retrieved from https://dif.org.ua/uploads/pdf/15439902275 aec4453ef5927.19702097.pdf [in 
Ukrainian].

22. Kovalenko, S.O. (2019). Finansova detsentralizatsiia v Ukraini ta yii perspektyvy [Financial decentralization in Ukraine and its prospects]. Retrieved from https://www.business-inform.net/export_pdf/ business-inform-2019-4_0pages-300_306.pdf [in Ukrainian].

23. Zhalilo, Ya.A., Makarov, H.V., Danyliak, O.O., Rudenko, A.F., Romanova, V.V., Pavlenko, I.A. \& Shevchenko, O.V. (2018). Detsentralizatsiia vlady: yak zberehty uspishnist $\mathrm{v}$ umovakh novykh vyklykiv? [Decentralization of power: how to maintain success in the face of new challenges?] Analitychna dopovid. Kyiv: Natsionalnyi instytut stratehichnykh doslidzhen [in Ukrainian].

24. SME Competitiveness Outlook 2018: Business Ecosystems for the Digital Age.- Geneva. ITC (2018) [in English].

\section{Відомості про автора / Information about the Authors}

Коваленко Наталія Вікторівна: Національна академія державного управління при Президентові України, вул. Антона Цедіка, 20, м. Київ, 03057, Україна

Nataliia Kovalenko: National academy for public administration under the President of Ukraine, Kyiv, 03057, Ukraine

\section{ORCID. ORG/ 0000-0001-8398-8381}

\section{E-mail: kovalenko_nadu@ukr.net}

